Галич О. А., доктор філологічних наук, професор, професор кафедри державного управління, документознавства та інформаційної політики Національного університету водного господарства та природокористування (м. Рівне)

\title{
ЕКСТРАПОЛЯЦІЯ ПОСТАТІ ФАНДОРІНА В ЄВРОПЕЙСЬКУ ІСТОРІЮ: «СОКІЛ І ЛАСТІВКА» Б. АКУНІНА
}

У статті проаналізовано екстраполячію постаті Ераста Петровича Фандоріна, героя багатьох романів, повістей, оповідань Бориса Акуніна, в європейську історію. Для иього автор розглядає роман “Сокіл $і$ Ластівка», у якому дійовими особами є його онук Ніколас та предки, зокрема Летіція фон Дорн. Події відбуваються у двох часових вимірах, у 1702 та 2009 роках. "Сокіл $і$ Ластівка" Б. Акуніна, як $і$ низка інших його романів, допомагають видати квазібіографію Фандоріна за життєпис реальної людини, що жила й творила в контексті справжніх історичних подій свого часу. Сам же Ераст Петрович особисто у творі не з'являється. Зате ми маємо його далеких предків і нащадків, щзо $\epsilon$ складниками ланиююжку у створеному фантазією автора родовому дереві героя.

Ключові слова: квазібіографія, біографія, екстраполячія, містифікачія, детектив.

The article analyzes the extrapolation of the figure of Erast Petrovych Fandorin, the hero of many novels, stories, short stories by Boris Akunin, into the European history. For this, the author considers the novel «Falcon and Swallow», in which characters are presented by his grandson Nicholas and his ancestors, in particular Letitia von Dorn. Events take place in two time periods, in 1702 and 2009. "Falcon and Swallow" by B. Akunin as well as a number of his other novels, contribute to give out the quasibiography of Fandorin as the biography of the real person who lived and worked in the context of real historical events of that time. Erast Petrovych himself personally does not appear in the work. But we have his distant ancestors and descendants, who are components of the chain in the generic tree of the hero created by the imagination of the author.

Key words: quasi biography, biography, extrapolation, mystification, detective.

B статье проанализировано экстраполяцию личности Эраста Петровича Фандорина, героя многих романов, повестей, рассказов Бориса Акунина, в европейскую историю. Для этого автор рассматривает роман “Сокол и Ласточка", в котором действующими лицами являются его внук Николас и предки, в частности Летиция фон Дорн. События происходят в двух временных измерениях, в 1702 и 2009 годах. "Сокол и Ласточка” Б. Акунина, как и ряд других его романов, помогают выдать квазибиографию Фандорина за жизнеописание реального человека, жившего и творившего в контексте настоящих исторических событий своего времени. Сам же Эраст Петрович лично в произведении не появляется. Зато мы видим его далеких предков и потомков, что являются звеньями цеепи в созданном фантазией автора родовом дереве героя.

Ключевые слова: квазибиография, биография, экстраполяџия, мистификация, детектив.

Сучасний російський письменник Б. Акунін (Г. Чхартишвілі) - автор понад 60 романів, повістей, збірок есеїстики, його книжки видані на більше ніж 30 мовах народів світу. Останні роки постійно проживає у Франції. В інтерв’ю українському журналісту Ю. Володарському він заявив: «Я не був дома з 2014 
року. Головним чином із-за “украйнського питання”. Я можу купити квиток $i$ полетіти в Росію. Ніщо мені там не загрожує. Але не хочу. Я повернуся, коли люди перестануть слухняно плестися за сопілкою Щуролова» [Акунин 2017:105].

20 років тому, у лютому 1998 року, побачив світ роман Б. Акуніна «Азазель», у якому вперше з'явився образ Ераста Петровича Фандоріна, колезького реєстратора, чиновника 14 класу. Роман пізніше розгорнувся в цілий цикл різножанрових творів, де описувалися його пригоди як талановитого сищика. Цей твір поклав початок своєрідній біографії, а точніше квазібіографії героя, якого автор послідовно буде вписувати в історію Російської імперії, розширивши згодом межі його життя екскурсами в далеке минуле родини Фандоріних, екстраполюючи його на внуків у новітній історії Росії і не тільки.

У жовтні 2017 року Б. Акунін заявив, що 8 лютого 2018 року, у день двадцятиріччя виходу роману «Азазель», що започаткував його фандоріану, вийде його останній роман про Фандоріна. Про Б. Акуніна чимало вже написано, але праць, у яких би розглядалася квазібіографія Ераста Петровича Фандоріна, немає.

Метою нашої розвідки $є$ спроба простежити, як у романі «Сокіл i Ластівка» автор прагне довести, що його герой - Ераст Петрович Фандорін має реальну біографію, а не квазібіографію, яка потверджується наявністю предків і нащадків. Події твору розгортаються у двох часових планах, у 2009 році, де головним героєм виступає онук Ераста Петровича Ніколас, поверненню якого 3 Англії до Росії присвячено роман «Алтин-толобас», та кілька століть тому, у 1702 році, тут маємо справу з далекими німецькими предками родини Фандоріних.

«Сокіл» i «Ластівка» входить до серії романів Б. Акуніна «Пригоди магістра» («Алтин-толобас», «Позакласне читання», «Ф. М.»), оскільки головним героєм у них є не сам Ераст Петрович Фандорін, а його онук Ніколас. Сучасні події твору розгортаються спершу в Москві, згодом на круїзному лайнері «Сокіл», а потім на маленькому острові в Карибському морі 3 
архіпелагу Антильські острови. Роман є квазібіографічним, оскільки одне з його завдань - це підтвердити справжність постаті знаменитого сищика Ераста Петровича Фандоріна, героя низки творів Б. Акуніна. Сам же Ераст Петрович особисто у творі не з'являється. Зате ми маємо його далеких предків, що є складниками ланцюжку у створеному фантазією автора родовому дереві героя.

У «Соколі» і «Ластівці» Ніколас Фандорін уже не гість Москви, а російський громадянин, одружений, у нього двоє дітей. Його дружиною виявилася московська журналістка Алтин, відома 3 роману «Алтин-толобас». Проте події на цей раз відбуваються не в російській столиці, а в Атлантиці: «Ніколас Фендорін (так звучало ім'я Миколи Олександровича на британський манер) опинився серед пасажирів тринадиятипалубного лайнера "Falcon" (“Сокіл” у перекладі 3 англійської - О.Г.), щзо прямував за мармрутом Саутгемптон - Кариби - Саутгемптон, не зі своєї волі. У “люкс-апартамент” круїзного теплоходу Ніку помістила воля двох жінок, і важко сказати, з якого боку на магістра був здійснений більший вплив» [Акунин 2009:15]. Перша 3 жінок була двоюрідною тіткою Ніколаса на ім’я Сінтія Борсхед. Вона була бездітною старою дівою, яка постійно з дитячих літ створювала героєві постійні проблеми, даруючи весь час безглузді подарунки. «Карибський круїз теж був подарунком - до 910-ліття роду Фандоріних. (Сам же Ніка колись $і$ дізнався, щзо перший фон Дорн отримав лищарські шпори в 1099 рощуі)» [Акунин 2009:17]. Ніколас не хотів нікуди їхати, але несподіваним союзником тітки виявилася дружина Алтин. Оскільки фірма Ніколаса «Країна Рад» ледве животіла, а журналістська праця Алтин все менше приносила прибутку, родина опинилася в скрутній матеріальній ситуації, яку спритна й наполеглива дружина вирішила поліпшити за рахунок тітки. «Бабуся, звичайно, пасажир тяжкий, - сказала Ніколасу дружина, - я тобі співчуваю. Але нічого, потерпиш. Вряди-годи зробиш щуось не для себе любого, а для родини. Бабуся на дев'ятому десятку, вона вийшла на фінішну пряму. Питання - кому дістанеться приз. Чи вона заповідає свої мільйони якомусь фонду з порятунку мухи цุеце, чи згадає, щэо в неї є бідний племінник, у котрого двоє важких дітей $i$ без $n$ 'яти хвилин 
безробітна дружина. Хай стара зараза полюбить тебе останньою немеркнучою любов'ю» [Акунин 2009:22].

Так Ніколас Фандорін опинився на борту океанського лайнера «Сокіл». Там несподівано для себе він дізнався, що Сінтія Борхед не випадково запросила його на теплохід. Вона хотіла, щоб Ніколас, якому в спадок передалися аналітичні здібності діда, допоміг їй розшукати скарби, заховані на одному з островів у Атлантиці.

Тітці вдалося дізнатися, що скарби зберігаються на острові Сент-Моріс десь у Карибському морі. Однак вона знала лише частину правди про місцезнаходження скарбів, тому долучила до експедиції ще двох компаньйонів, які мали певні свідчення про іншу частину правди, містера Делоні та мсьє Міньйона. Обидва вони виявилися нащадками тих героїв роману «Сокіл i Ластівка», які відомі з сюжетної лінії, події якої відбуваються понад триста років тому, у 1702 році.

Історія зі скарбами, події якої відбуваються в наш час, є своєрідним обрамленням роману. Перша іiі частина присвячена поступовому розумінню Ніколасом суті його місії. У другій частині обрамлення йдеться безпосередньо про пошуки скарбів, у яких разом 3 Ніколасом беруть участь компаньйони тітоньки Сінтії Борхед Делоні та Міньйон. Зазнавши невдачі в пошуках, маленька експедиція полишає острів Сент-Моріс. На зворотному шляху Ніколасу несподівано приходить розгадка, де можуть бути сховані скарби капітана Джеремі Пратта. Він вимагає повернутися назад i висадити його одного на острів. І це розв'язка роману. Автор нічого не говорить про знайдені Ніколасом скарби, але з підтексту зрозуміло, що він буде володіти ними.

Історія зі скарбами у романі Б. Акуніна прямо пов’язана предками Фандоріна, зокрема Летіцією фон Дорн, що буде головною героїнею тієї сюжетної лінії роману, у якій розповідається про події, пов’язані з пошуками скарбів у 1702 році, свідком і учасником котрих стала ця молода жінка, 3'явившись на кораблі «Ластівка» в чоловічому вбранні як корабельний лікар Люсьєн Епін. 
Доля цієї героїні розгортається в детективному плані. Летіція фон Дорн як найближча попередниця російської гілки роду Фандоріних, чий дядя на ім'я Корнеліус (один із головних героїв роману «Алтин-толобас») згинув десь у холодній Московії, долає безліч пригод, переживає низку смертельних подій, щоб дізнатися таємницю схованих скарбів. Листи Летіції фон Дорн своїй далекій родичці Беттіні фон Герц, під якими стоїть підпис Люсьєн Епін, стали ключем у пошуках скарбів капітана Джеремі Пратта, учасником яких став Ніколас Фандорін.

У долі Летіції фон Дорн важливу роль відіграв англійський лорд Руперт Грей, який відмовився від величезного спадку заради плавання в океані на власному судні «Русалка». Опинившись волею долі у полоні на “Ластівці”, він був врятований закоханою в нього Летіцією, і вони залишилися на острові, на якому вона виявила заховані скарби капітана Джеремі Пратта. Остання картина, створена уявою Б. Акуніна, залишає читачів бути впевненими, що закохані щасливі на острові: «Летіція і Грей сиділи на піску поруч, охопивши один одного за плечі, і про щзось тихо розмовляли» [Акунин 2009:544].

Про те, що твір є квазіобіографічним свідчить блог Ніколаса Фандоріна, «який Микола Олександрович вів з першого дня подорожі» [Сокіл:26]. Блог (від англ. blog) - інтернет-журнал певних подій, який веде конкретна людина, блогер. Як правило, блогер для своїх записів обирає певний нік, своєрідний псевдонім, що використовується замість імені в Інтернеті. Ніколас у Б. Акуніна стає Довгим Джоном, так звався пірат у романі «Острів скарбів» Р. Л. Стівенсона, який в дитинстві читав герой твору. Функція блогу Ніколаса в романі Б. Акуніна полягає в переконанні читачів, що вони мають справу 3 реальними подіями, які потверджуються записами головного героя, який описує перебіг подорожі: «Відпливли вчора увечері, але писати не міг. Хоча в рекламній брошурі обіияли, щуо морська хвороба пасажсиам “Фалкону” не страшна, мене сильно занудило, ледве теплохід вийшов у Ла-Мани. Погода мерзотна. Сильний вітер, дощу»[Акунин 2009:28]; «Вранщ̧і стало кращее, і я зміг оглянути нашу чудесну каюту, а потім i теплохід» [Акунин 2009:29]. На підтвердження 
справжності подій з Довгим Джоном в блогосфері листується дружина, яка давно вже мала нік «Болід», оскільки працювала в журналі, де вела шефредакторський блог. Вона пише коротко, але весь час повчаючи чоловіка, якого вважає слабкодухим i слабохарактерним: «Морська хвороба походить від слабовілля і розслабленості. Нею страждають тільки нероби. Ходи в джім, бігай по палубі, і все мине» [Акунин 2009:30].

До листування залучалася й секретар Ніколаса Валя, яка днювала й ночувала в Інтернеті. Про мовні здібності цієї епізодичної героїні Б. Акунін пише 3 іронією: «Валентина отримала неупорядковану освіту. Швидко торохтіла на іноземних мовах, але рідною володіла нетвердо - особливо орфографією. Ось чому вона з ентузіазмом підхопила моду писати по-албанськи, де безграмотність піднесена до принщ̧ипу...» [Акунин 2009:27]. Один 3 iї блогів має такий вигляд (його варто процитувати в оригіналі): «Сиводне падбило бапки зо мард. Буголтерие жудь. Расхлдафф двесте деветь тылщ ни щзетая маей sо salled зорплатэ, каторую магу падаждать. Даходафф шыли. Папутнава ветро» [Акунин 2009:36].

Б. Акунін у своїй творчості часто вдається до експериментів. Не становить винятку і його роман «Сокіл і Ластівка». Наскрізним героєм твору $є$ японська папуга чоловічого роду, 3 якою вперше стикається Ніколас у бібліотеці океанського лайнера: «...На столику реєстратури сиділа велетенська папуга вишуканого, але дещуо траурного забарвлення: сама чорна, 3 червоним чубчиком $i$ жовтою облямівкою вздовж крил. Птах водив здоровенним дзобом по сторінці розкритої книжки - ніби читав» [Акунин 2009:52-53]. Ця папуга супроводжує життя героїв на початку вісімнадцятого століття і в наш час. Розділ перший - «Життя і роздуми АндокуМінхера-Каброна-Трюка» - це монолог народженої в Японії папуги на ім'я Трюк, що раніше носила імена Андоку, Мінхер, Каброн. Для того, щоб орнітологічний образ папуги був функціональним у тексті, автор наділяє його довгим життям і власною історією, у витоків якої стояв Учитель, котрий порятував птаха, дав йому перше ім’я Андоку (Мирна Самотність), 
накресливши подальшу долю. Перед смертю учитель передав Андоку свій Мансей - Дар Повного Життя: «Той, хто володіє Даром Повного Життя, не безсмертний $i$ не захищений від небезпек, але позбавлений від постаріння $i$ ніколи не хворіє» [Акунин 2009:103]. Цей художній прийом дозволив Б. Акуніну ніби з боку спостерігати за розвитком подій у XXVIII i XXI ст. Папуга перебуває поруч з Летіцією фон Дорн і Ніколасом Фандоріним, супроводжує у всіх пригодах. Часом здається, що саме папуга є тим наратором, від лиця якого ведеться оповідь у романі «Сокіл і Ластівка».

Навіть у заключному епізоді твору, його розв’язці, коли Ніколас наказує повернути човен назад на острів Сент-Моріс, присутній папуга: йому «набридло бавитися з вітрилом. Він придумав нову розвагу. Розчепіривии чорно-червоні крила, носився над самими хвилями, розсікаючи кігтями воду. У всі боки летіли бірюзові бризки. Виходило красиво» [Акунин 2009:616].

Творячи свою фандоріану, Б. Акунін іде на сміливі експерименти 3 формою та змістом циклу текстів, використовуючи різні жанри та жанрові різновиди, однак щоразу залишаючи головне - все в романах, повістях, оповіданнях повинно працювати заради творення квазібіографіï наскрізного героя, впровадження його в контекст російської та європейської історій. Цьому сприяють також твори, дотичні до фандоріани, у яких діють його предки та нащадки.

«Сокіл i Ластівка» Б. Акуніна, як i низка інших його романів, допомагають екстраполювати образ Ераста Петровича Фандоріна в європейську, а деяких моментах навіть у світову історію, видавши його квазібіографію за життєпис реальної людини, що жила й творила в контексті справжніх історичних подій свого часу.

\section{БІБЛІОГРАФІЯ}

Акунин 2017 - Акунин Борис. Приросшая маска / Борис Акунин // Шо : журнал про сучасну культуру. - № 11/16-2/17. - ноябрь 2016 - февраль 2017. К. : Изд. дом “Чили”. - С. $102-105$. 
Акунин 2009 - Акунин Борис. Сокол и Ласточка / Борис Акунин. - М. : ОЛМА Медиа Групп, 2009. - 624 с. 